\title{
Hydrological Study and Aquifer Characteristics Evaluation of Wadi El Arab Catchment Area/Jordan
}

\author{
Naser Al Manaseer ${ }^{1}$ and RakadTa'any ${ }^{2} *$ \\ ${ }^{1}$ Department of Civil Engineering, Faculty of Engineering, AlBalqa Applied University, \\ Al-Al Salt19117, Jordan \\ ${ }^{2}$ Department of Water Resources and Environmental Management, Faculty of Agricultural \\ Technology, AlBalqa Applied University, Al-Salt19117, Jordan \\ *Corresponding author
}

\section{Keywords}

Water resources, Curve number, Evaporation, Pollution, Catchment area

Article Info

Accepted:

17 October 2019 Available Online:

10 November 2019
This study deals with Hydrological study and aquifer characteristics evaluation of Wadi Arab Catchment area/Jordan; Wadi El-Arab covers an area of about 267 $\mathrm{km}^{2}$. The catchment lies between $210-230 \mathrm{~N}$ and $208-230 \mathrm{E}$ according to Palestinian grids. There are several Wadis draining in the catchment area and no flow measurement data are available for these Wadis. The main objectives of this paper are to provide a hydrological and hydrogeological assessment for the water resources of Wadi El -Arab catchment area. Also to calculate the water budget and specify the different pollutants, their possible sources and their actual impacts on the groundwater resources. The determination of flows is carried out by applying the "Curve Number" approach of the "United States Soil Conservation Service (SCS)" to the available rainfall data. The average annual rainfall for the period $1980-2018$ is $426.42 \mathrm{~mm}$, the rate of evaporation ranges between $83 \%$ in the wet year and $90 \%$ in the extremely dry water year. The infiltration rate ranges between 6.75 percent and 10.61 percent. While the rate of Runoff ranges between $6.55 \%$ in the wet year and $3.25 \%$ in the extremely dry water year. The hydraulic system of Wadi El-Arab Basin is controlled by the geological and structural conditions, which also controls the recharge level, movement, and discharge of the groundwater. The aquifer systems of the entire study area are related to the Cretaceous Upper Ajlun Group $\left(\mathrm{A}_{7}\right)$ to the Cenozoic Lower Belqa Group $\left(\mathrm{B}_{1}\right.$ and $B_{2}$ ) is the main aquifer for water supply in the study area. On its top, the $A_{7} / B_{2}$ aquifer is hydraulically separated from the locally productive $\mathrm{B}_{4}$ aquifer by the Muwaqqar aquitard $\left(B_{3}\right)$. The transmissivity of the $\left(B_{2} / A_{7}\right)$ aquifer ranges from 9 $\mathrm{m}^{2} /$ day to more than $900 \mathrm{~m}^{2} /$ day. The storage coefficient of this aquifer in the confined condition vary from $10^{-3}$ to $10^{-5}$, while the specific capacity vary from less than $0.01 \mathrm{~L} / \mathrm{s} / \mathrm{m}$ to more than $50 \mathrm{~L} / \mathrm{s} / \mathrm{m}$ and The permeability ranges from 0.01 to more than $100 \mathrm{~m} /$ day. 


\section{Introduction}

Water is an essential element of nature and is the elixir of life. The increasing water demand by population growing, industrialization, agriculture, and rising of living standards have led to increase the stresses on these resources. Water resources are decreasing due to unawareness of people as they think that water is renewable; this unawareness led to exploitation of all available water resources which and cause water quality deterioration.

Jordan has been classified recently as second poorest country of water resource. Due to unreliable and shortages in the supply of water sector, this makes it very difficult to face the required increasing demand.

Surface and groundwater sources are used to meet Jordan water demand. The groundwater extractions often exceed the natural recharge volumes, resulting in a decline of the groundwater table and in a deterioration of the soil and water quality.

The present paper focuses on the current situation of the water resources at Wadi ElArab catchment area. Wadi El-Arab catchment area enjoys a Mediterranean to semi-arid climate, with hot and dry summer, cool and wet winter. The average annual rainfall is approximately ranges between $350 \mathrm{~mm}$ and 500mm (JMD, 2012).

The importance of this catchment area is that it contains perennial springs which exist only in the northwest part, and these springs are the main source of potable water for Irbid city, however, these springs dried out due to severe pumpage which started before 20 years ago. In the last decade, the groundwater level in Wadi El-Arab wells drop in a rate exceeded $25 \mathrm{~m}$ (Shatnawi and Diabat, 2016). Consequently, the aquifer balance is disturbed and a major decline in water level accompanied by deterioration in groundwater quality has taken place. The extension of urban area around the main springs, and the existence of Irbid and Wadi El Arab, which affect the water uses. These issues guided me to evaluate the water resources of the study area.

\section{Physiography}

Wadi Al Arab drainage catchment with an area of $267 \mathrm{~km}^{2}$ is situated on the East Bank of Jordan Rift Valley about $10 \mathrm{~km}$ south of Lake Tiberius. The selected catchment area lies within $32^{\circ} 34^{\prime} 60^{\prime \prime} \mathrm{N}$ and $35^{\circ} 34^{\prime} 60^{\prime \prime}$ E latitude or between $210-230 \mathrm{~N}$ and 208-230E according to Palestinian grids (Figure 1).

The topography ranges from rolling hills in the East to steeper mountainous areas in the North and West. The general slope of the area is from East to West, that's from $800 \mathrm{~m}$ above the mean sea level (asl) at highlands south of the study area to less than $130 \mathrm{~m}$ below the mean sea level (bsl) at the site of dam (Figure 2).

Despite the small area of Wadi El-Arab catchment area, a very heterogeneous soil can be found. The major causes of this variety are the extreme climate conditions which form these soils in addition to variable geology (sedimentary rocks, alluvium, etc.) different topographic features and physical weathering from both water and wind modifies the soils, Figure 3 describes the different types of soil that are present in the catchment area, (MOA, 1994).

Wadi El-Arab drainage basin is a highly valuable agricultural land, fertile soil, the nature of slope and soil of this catchment making it suitable for cultivation. It is intensively cultivated with olives cereals and vegetables in the upper southern slopes of Wadi El-Arab an oak forest grows, while in northern slope it cultivated with pine, Figure 4 
shows the different types of soil that present in the catchment area.

\section{Materials and Methods}

\section{Geology and hydrogeology}

The geological material existing in the catchment area is the important features affecting the hydrology regime. The flow rate of the surface water and subsurface water influenced by the nature of the bed material. The outcropping formations in Wadi El - Arab catchment range in age from Late Cretaceous to Quaternary sediments, basically the Ajlun (A) and Balqa(B) group. These deposits are divided into three groups, Kurnub (K), Ajlun (A) and Belqa (B) group in ascending order. the Belqa /Ajlun group (B/A) is underlain by the Kurnub $(\mathrm{K})$ layer composed of sandstone layers of lower cretaceous period, which crops out at the lower limit of Wadi Shu'eib catchment area. The A/B (two groups of middle to upper cretaceous) is divided into several formations of $\mathrm{A} 1$ to $\mathrm{A} 7$, and $\mathrm{B} 1$ to $\mathrm{B} 2$. Some of the formation might strictly be considered as (sub-groups) and the groups as (super groups) but the division has been based on previously used mapping units and on a general classification of units into aquifers and Aquicludes. For those units which could be further divided, a double number has been assigned. For example, the A1/2 formation, the Na'ur limestone and marl formation can be split in some districts and this has been done wherever possible, (Shatnawi and Diabat, 2016).

The geological structure and tectonic features in the Wadi EL-Arab Catchment Area is highly related to the structure of Jordan Rift Valley, which was described in detailed by many authors. Uplifting and faulting has considerably affected the rock formations along the Jordan Valley Escarpment and further to the east (Figure 5).
The hydraulic system of Wadi El-Arab Basin is controlled by the geological and structural conditions, which also controls the recharge level, movement, and discharge of the groundwater. The aquifer systems of the entire study area are related to the Cretaceous Upper Ajlun Group $\left(\mathrm{A}_{7}\right)$ to the Cenozoic Lower Belqa Group $\left(B_{1}\right.$ and $\left.B_{2}\right)$ is the main aquifer for water supply in the study area. On its top, the $A_{7} / B_{2}$ aquifer is hydraulically separated from the locally productive $\mathrm{B}_{4}$ aquifer by the Muwaqqar aquitard $\left(\mathrm{B}_{3}\right)$. The transmissivity of the $\left(B_{2} / A_{7}\right)$ aquifer ranges from $9 \mathrm{~m}^{2} /$ day to more than $900 \mathrm{~m}^{2}$ /day. The storage coefficient of this aquifer in the confined condition vary from $10^{-3}$ to $10^{-5}$, while the specific capacity vary from less than $0.01 \mathrm{~L} / \mathrm{s}$ $/ \mathrm{m}$ to more than $50 \mathrm{~L} / \mathrm{s} / \mathrm{m}$ and The permeability ranges from 0.01 to more than $100 \mathrm{~m} /$ day, (BGR and MWI, 2001).

\section{Data preparation under ArcGIS software environment}

The geological formation of the study area has been identified by using the geological map from Natural Resources Authority (NRA). This stage included geo-referencing and scanning the available maps, after that digitizing the classified formation then symbolized the categories. The same process was applied to the different paper maps such as (soil map, geology map, aquifer media, and the land use map).

On the other hand, the topography of the study area has been achieved by using the DEM; which is displaying the geomorphology of the catchment area.

\section{Determination of the areal rainfall}

There are eight rainfall stations in the study area; all stations measure the daily rainfall, and five of them have also rainfall recorders, giving hourly rainfall events. The distribution 
of rainfall over the study area was represented in two methods; these are Thiessen polygon technique and Isohyethal method. Thiessen polygon was applied to estimate the areal rainfall for each considered storm. In this method it is assumed that the point rainfall at the station is representing the areal rainfall in its polygon, or its area of rainfall influence. Figure 6, shows the Thiessen polygons of Wadi El Arab catchment area.

\section{Runoff}

There are no gauging stations located in Wadi El Arab Catchment Area. Therefore, the US Soil conservation services method (SCS), was applied to calculate the runoff occurred from different storms of normal condition,(Aydin and Antal, 2019), This method takes in consideration the antecedent moisture conditions (AMC), the initial abstraction of rainfall, and the land use.

The first step for the use of the SCS model was to estimate the volume of direct of runoff, (Q), in inches.

$\mathrm{Q}=\left(\mathrm{P}-\mathrm{I}_{\mathrm{a}}\right)^{2 /}\left(\mathrm{P}-\mathrm{I}_{\mathrm{a}}+\mathrm{S}\right) \ldots(1),($ Chow et. al, 1988)

Where

Q: is the accumulated depth of runoff in inches.

$\mathrm{P}:$ is the accumulated depth of storm rainfall in inches.

$\mathrm{I}_{\mathrm{a}}$ : is the depth of the initial abstraction in inches.

$\mathrm{I}_{\mathrm{a}}$ and $\mathrm{S}$ are related to soil cover conditions. Also the relation between initial abstraction $\left(\mathrm{I}_{\mathrm{a}}\right)$ and potential abstraction $(\mathrm{S})$ was derived from the studies of different watersheds in the United States of America as,
$\mathrm{I}_{\mathrm{a}}=0.2 \mathrm{~S} \ldots(2)$

The above equation for the accumulated runoff is formulated as:

$\mathrm{Q}=(\mathrm{P}-0.2 \mathrm{~S})^{2} /(\mathrm{P}+0.8 \mathrm{~S}) \ldots(3)$

The relation between the Curve Number $(\mathrm{CN})$ And S was established by (Wanielista,1990) as,

$\mathrm{S}=(1000 / \mathrm{CN})-10 \ldots(4)$

These universal equations are the basis of the runoff model used in this study where the flows were derived.

\section{Evapotranspiration}

The purpose of calculating the evapotranspiration in Wadi Shu'eib Catchment area is to estimate the direct recharge into the groundwater of the Upper aquifer system (B4). The potential evapotranspiration was calculated using Turc Equations. This equation is written as follows:

$E=P /\left(\sqrt{0.9+\left(P^{2} / f(t)^{2}\right)} \ldots .(5), \quad\right.$ (Turc, 1990)

Where

E: the annual actual evaporation (mm)

$\mathrm{P}$ : the average annual precipitation ( $\mathrm{mm})$

$\mathrm{T}$ : the temperature function, which is equal to,

$f(t)=300+25 t+0.05 t^{3} \ldots(6)$

The essential climatological data which were needed for the computation of the potential evapotranspiration had been collected from Ministry of water and irrigation (MWI, 2017). In order to obtain the actual evaporation from 
rainfall, the potential evaporation was calculated during the occurrence of the rainfall storm.

\section{Results and Discussion}

\section{Hydrogeological setting}

The hydraulic system of Wadi El-Arab Basin is controlled by the geological and structural conditions, which also controls the recharge level, movement, and discharge of the groundwater. The aquifer systems of the entire study area are related to the Cretaceous Upper Ajlun Group $\left(A_{7}\right)$ to the Cenozoic Lower Belqa Group ( $\mathrm{B}_{1}$ and $\left.\mathrm{B}_{2}\right)$ is the main aquifer for water supply in the study area. The $A_{7} / B_{2}$ aquifer is hydraulically separated from the locally productive $\mathrm{B}_{4}$ aquifer by the Muwaqqar aquitard $\left(\mathrm{B}_{3}\right)$.

\section{Aquifer Systems}

The main aquifer systems are as follows:

Muwaqqar formation (B3) has low permeability, and consists of marl and marlylimestone, so it considered as aquitard. The thickness of this formation is more than $300 \mathrm{~m}$, in the study area this formation has been slightly eroded, (MWI,2017).

Umm Ghudran - Amman formation $\left(\mathrm{B} 1_{/ 2}\right)$ thickness ranges between $140-200 \mathrm{~m}$, it considers as good aquifer, and consists of chert and phosphatic beds and chalky limestone.

Wadi Es-Sir formation $\left(\mathrm{A}_{7}\right)$ the thickness is varied from $190 \mathrm{~m}$ to less than $300 \mathrm{~m}$ and is considered as good aquifer, it consists from white to light grey semi-crystalline limestone and dolomitic limestone, becomes more chalky towards the base of the unit. The $A_{7}$ formation and the overlying $\mathrm{B}_{1 / 2}$ formations are one hydrogeological it is known as the
$\mathrm{B}_{2} / \mathrm{A}_{7}$ aquifer. $\mathrm{A}_{5 / 6}$ formation the base system in the Wadi El-Arab area is marly $\mathrm{A}_{5 / 6}$ aquitard which overlying $\mathrm{B}_{2} / \mathrm{A}_{7}$ aquifer system, thickness of this layer is from 100 to $150 \mathrm{~m}$, it characterizes by low permeability, and it is specified by yellowish marl with limestone, dolomite, and shale.

The flow net map gives the ordinary trend in groundwater flow direction and assist in the approximate delineation of groundwater of the Wadi El-Arab well field, Figure 7.

Groundwater recharge take places in the outcrop area of the $\mathrm{B}_{2} / \mathrm{A}_{7}$ aquifer in the central part of the catchment and the mountains south of Irbid, at which the $\mathrm{B}_{2} / \mathrm{A}_{7}$ unit is not saturated. The other parameters contribute in groundwater recharge, is the infiltrating rain water, which follows the dip in slope to north directions.

The direction of the groundwater flow is from eastern part of the catchment to the western part of the catchment that means from highlands to lowlands of the catchment. The transmissivity of the $\left(\mathrm{B}_{2} / \mathrm{A}_{7}\right)$ aquifer ranges from $9 \mathrm{~m}^{2} /$ day to more than $900 \mathrm{~m}^{2} /$ day. The storage coefficient of this aquifer in the confined condition vary from $10^{-3}$ to $10^{-5}$, while the specific capacity vary from less than $0.01 \mathrm{~L} / \mathrm{s} / \mathrm{m}$ to more than $50 \mathrm{~L} / \mathrm{s} / \mathrm{m}$ and The permeability ranges from 0.01 to more than $100 \mathrm{~m}$ /day, (BGR and MWI 2001).

\section{Water balance}

\section{Mean annual rainfall}

For hydrologic analysis and process, it is important to know the areal distribution of rainfall. The most common methods used are the Isohyethal method and Thiessen method. To determine the areal rainfall, there are two basic methods and these are Thiessen method and Isohyethal method, Thiessen method of 
the catchment area subdivided the catchment area into polygons with the rain gauge in center. The weighted average for each polygon was utilized to evaluate the average rainfall in the study area.

Thiessen method is not preferable to use in mountainous region due to the influence of orographic. Table 1, shows the weighted area for each polygon and Figure 6 shows the Thiessen polygon of the study area.

The Isohyethal method is the most accurate approach to determine the average annual rainfall depth over an area for a proper use; it requires a skilled analyst and careful attention to topographic and other factors that effect on areal variability. Isohyethal map is used to show the mean annual rainfall over the catchment, Figure 8. The lowest annual rainfall of $250 \mathrm{~mm}$ falls over the western part of the studied area and the highest of $430 \mathrm{~mm}$ in Irbid station. Generally, the rainfall gradually decreases towards the Jordan Valleys.

\section{Runoff}

As discussed in the materials and methods section, there are no runoff gauging stations available at the Wadi El-Arab Catchment area. Accordingly, runoff is calculated using the SCS Curve Number Method, which relates storm runoff to rainfall by a relationship that depends primarily upon the potential abstraction of water by soil storage. High potential abstraction means less runoff for a given rainfall, represented by a lower curve number (Aydin and Antal, 2019).

The result of calculations, based on SCS method, it was found that, the average annual surface runoff for the normal year is 25.04 $\mathrm{mm}$, for the wet year $37.38 \mathrm{~mm}$ and $12 \mathrm{~mm}$ in the dry water year condition, which represents $5.31 \%, 6.55 \%, 3.25 \%$ of the annual rainfall rate of the annual rainfall rate for normal, wet, dry years, respectively. Tables (2, 3 and 4) show the calculation of runoff for different water years using SCS - CN method.

Table.1 Rainfall station and area covered in study area

\begin{tabular}{|c|c|c|c|}
\hline Station Name & Station_IDN* & Area $\left.\mathbf{( K m}^{\mathbf{2}}\right)$ & Cover percentage \\
\hline Husn & AD0010 & 6.5 & 2.44 \\
\hline Al-Taiyiba & AB0001 & 21.01 & 7.91 \\
\hline Irbid & AE0002 & 10.94 & 4.12 \\
\hline Kafr Yuba & AE0003 & 58.31 & 21.95 \\
\hline Kafr Asad & AE0004 & 87.89 & 33.08 \\
\hline Um Qeis & AD0005 & 21.78 & 8.2 \\
\hline Irbid School & AE0001 & 56.17 & 21.14 \\
\hline Baqura & AD0032 & 3.06 & 1.16 \\
\hline Total & & $\mathbf{2 6 5 . 6 6}$ & $\mathbf{1 0 0}$ \\
\hline
\end{tabular}

*IDN: Identification Number 
Table.2 Estimation of the surface runoff using curve number method in the normal water year condition

\begin{tabular}{|c|c|c|c|c|c|c|c|c|c|c|c|c|c|}
\hline \multirow{4}{*}{$\begin{array}{c}\text { Water } \\
\text { year } \\
(2010 \\
- \\
2011)\end{array}$} & month & $\begin{array}{c}\text { Al- } \\
\text { Taiyiba }\end{array}$ & $\begin{array}{l}\text { Um } \\
\text { Qeis }\end{array}$ & Husn & Baqura & $\begin{array}{l}\text { Kafr } \\
\text { Asad }\end{array}$ & $\begin{array}{l}\text { Kafr } \\
\text { Yuba }\end{array}$ & $\begin{array}{c}\text { Irbid } \\
\text { School }\end{array}$ & $\begin{array}{l}\text { Irbid } \\
\text { Agr }\end{array}$ & $\underset{(\mathbf{m m})}{\mathbf{S}}$ & $\begin{array}{c}\text { Ia } \\
(\mathbf{m m})\end{array}$ & $\begin{array}{c}\mathbf{Q} \\
(\mathbf{m m})\end{array}$ & $\begin{array}{l}\text { Annual } \\
\text { Runoff }\end{array}$ \\
\hline & Dec & 1.96 & 0.96 & 0.31 & 0.165517 & 1.03 & 0.00 & 0.04 & 1.05 & 108.68 & 21.77 & 5.52 & \multirow[t]{3}{*}{25.04} \\
\hline & Feb & 0.82 & 0.26 & 0.41 & 0.07 & 4.90 & 1.30 & 0.11 & 1.54 & 108.68 & 21.77 & 9.41 & \\
\hline & Mar & 1.05 & 0.49 & 0.01 & 0.082 & 1.09 & 2.02 & 0.07 & 0.03 & 108.68 & 21.77 & 4.83 & \\
\hline
\end{tabular}

Table.3 Estimation of the surface runoff using curve number method in the dry water year condition

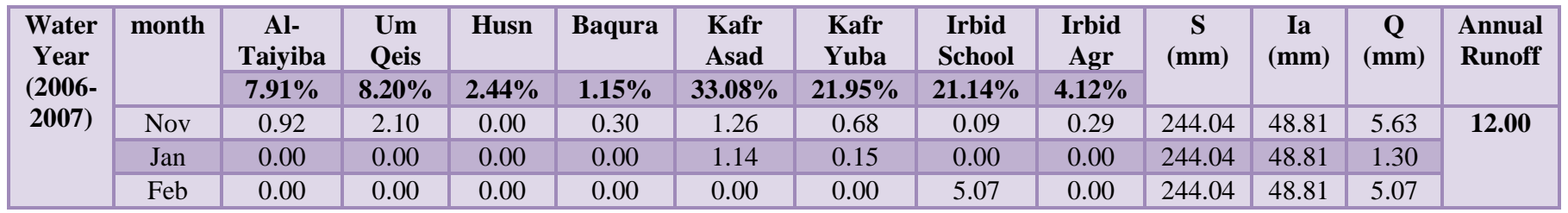

Table.4 Estimation of the surface runoff using curve number method in the wet water year condition

\begin{tabular}{|c|c|c|c|c|c|c|c|c|c|c|c|c|c|}
\hline \multirow{9}{*}{$\begin{array}{c}\text { Water } \\
\text { Year } \\
(2014- \\
2015)\end{array}$} & month & $\begin{array}{c}\text { Al- } \\
\text { Taiyiba }\end{array}$ & $\begin{array}{l}\text { Um } \\
\text { Qeis }\end{array}$ & Husn & Baqura & $\begin{array}{l}\text { Kafr } \\
\text { Asad }\end{array}$ & $\begin{array}{l}\text { Kafr } \\
\text { Yuba }\end{array}$ & $\begin{array}{c}\text { Irbid } \\
\text { School }\end{array}$ & $\begin{array}{c}\text { Irbid } \\
\text { Agr }\end{array}$ & \multirow[t]{2}{*}{$\begin{array}{c}\mathbf{S} \\
(\mathbf{m m})\end{array}$} & \multirow[t]{2}{*}{$\begin{array}{c}\text { Ia } \\
(\mathbf{m m})\end{array}$} & \multirow[t]{2}{*}{$\begin{array}{c}\mathbf{Q} \\
(\mathbf{m m})\end{array}$} & \multirow[t]{2}{*}{$\begin{array}{l}\text { Annual } \\
\text { Runoff }\end{array}$} \\
\hline & & $7.91 \%$ & $8.20 \%$ & $2.44 \%$ & $1.15 \%$ & $33.08 \%$ & $21.95 \%$ & $21.14 \%$ & $4.12 \%$ & & & & \\
\hline & Oct & 0.27 & 0.07 & 0.001 & 0.30 & 0.72 & 0.46 & 0.00 & 0.09 & 44.82 & 8.96 & 0.20 & \multirow[t]{7}{*}{37.38} \\
\hline & Nov & 3.91 & 7.16 & 0.66 & 0.25 & 32.55 & 10.19 & 19.12 & 2.74 & 44.82 & 8.96 & 9.54 & \\
\hline & Dec & 0.46 & 0.66 & 0.13 & 0.19 & 1.41 & 1.64 & 10.21 & 0.34 & 44.82 & 8.96 & 1.86 & \\
\hline & Jan & 4.19 & 3.42 & 1.95 & 0.15 & 46.60 & 6.3655 & 27.54 & 2.29 & 44.82 & 8.96 & 11.54 & \\
\hline & Feb & 4.10 & 0.32 & 1.40 & 1.19 & 46.60 & 10.19 & 27.60 & 2.94 & 44.82 & 8.96 & 11.65 & \\
\hline & Apr & 0.24 & 1.34 & 0.13 & 0.34 & 7.73 & 1.78 & 8.42 & 0.49 & 44.82 & 8.96 & 2.52 & \\
\hline & May & 0.00 & 0.00 & 0.00 & 0.00 & 0.00 & 0.00 & 0.637 & 0.00 & 44.82 & 8.96 & 0.081 & \\
\hline
\end{tabular}

Table.5 The annual evaporation for wet, normal and dry water years using Turc equation.

\begin{tabular}{|c|c|c|c|c|c|}
\hline Condition & water year & Mean (T) & $\begin{array}{c}\text { Annual } \\
\text { Rainfall (mm) }\end{array}$ & f (t) & $\begin{array}{c}\text { Evaporation } \\
(\mathbf{m m})\end{array}$ \\
\hline Normal & $2010 / 2011$ & 13.206 & 471.86 & 745.31 & 362.74 \\
\hline Wet & $2014 / 2015$ & 14.22 & 570.76 & 799.27 & 404.81 \\
\hline Dry & $2006 / 2007$ & 12.13 & 368.67 & 692.49 & 311.52 \\
\hline
\end{tabular}

Table.6 The water balance for Wadi El Arab catchment area (Normal, wet and dry conditions).

\begin{tabular}{|c|c|c|c|c|c|c|c|c|}
\hline Condition & water & $\begin{array}{c}\text { Annual } \\
\text { year }\end{array}$ & $\begin{array}{c}\text { Annual } \\
\text { (mm) }\end{array}$ & $\begin{array}{c}\text { Runoff } \\
\text { Runoff } \\
(\mathbf{m m})\end{array}$ & $\begin{array}{c}\text { Evaporatio } \\
\text { Rate\% }\end{array}$ & $\begin{array}{c}\text { ET Rate } \\
\mathbf{( m m})\end{array}$ & $\begin{array}{c}\text { Infiltratio } \\
\mathbf{n}\end{array}$ & $\begin{array}{c}\text { Inf Rate } \\
\text { \% }\end{array}$ \\
\hline Normal & $2010 / 2011$ & 471.863 & 25.04 & $5.31 \%$ & 362.74 & $76.87 \%$ & 84.083 & $17.82 \%$ \\
\hline Wet & $2014 / 2015$ & 570.76 & 37.38 & $6.55 \%$ & 404.81 & $70.92 \%$ & 128.57 & $22.53 \%$ \\
\hline Dry & $2006 / 2007$ & 368.67 & 12 & $3.25 \%$ & 311.52 & $84.50 \%$ & 45.15 & $12.25 \%$ \\
\hline
\end{tabular}


Fig.1 Location map of Wadi Al Arab drainage catchment area.

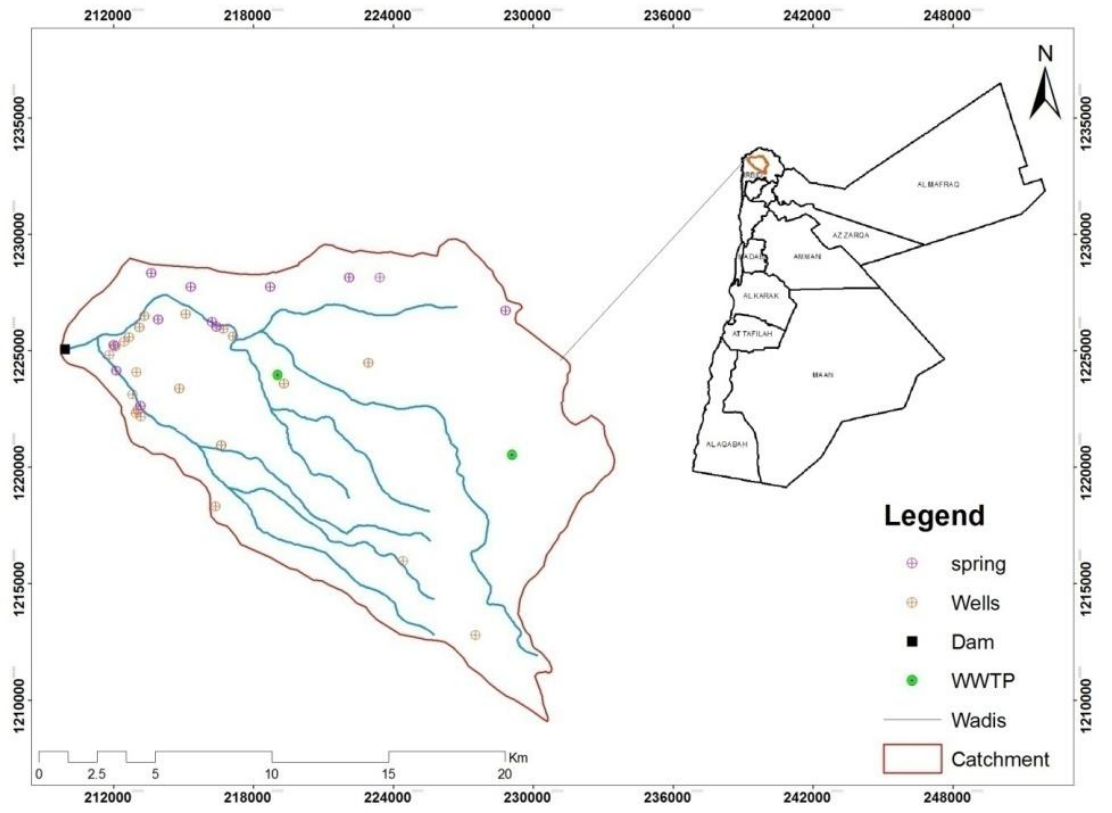

Fig.2 Wadi Al Arab drainage catchment area (Al-Adwan, 2018)

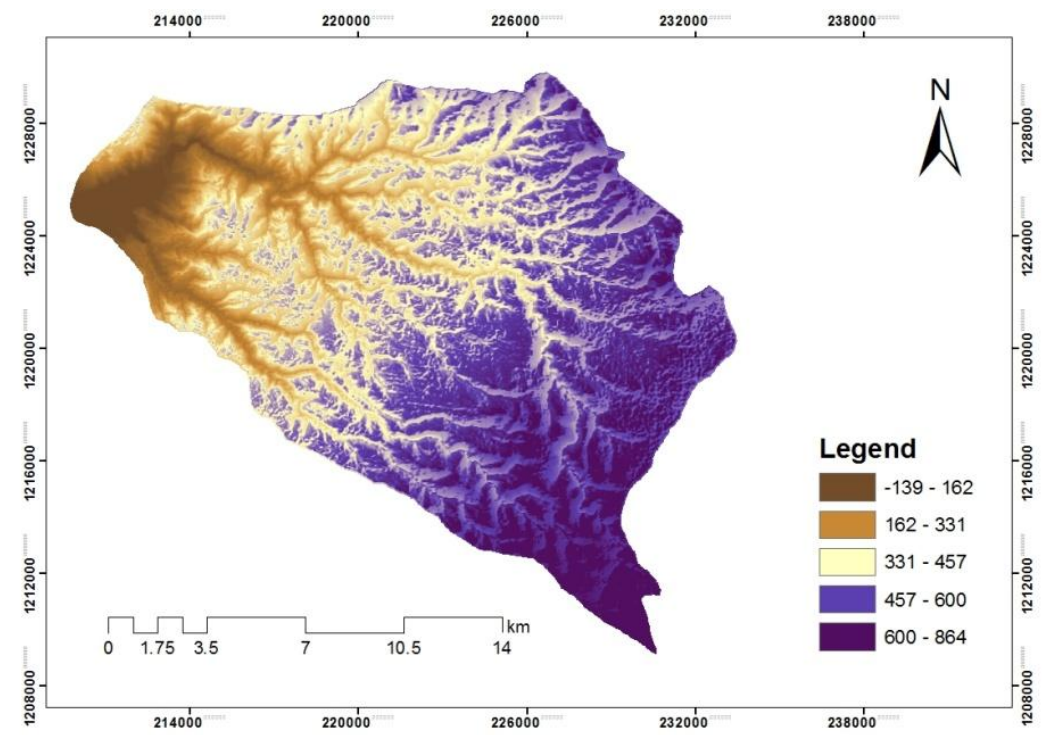


Fig.3 Soil map of Wadi El-Arab catchment area (MOA, 1994)

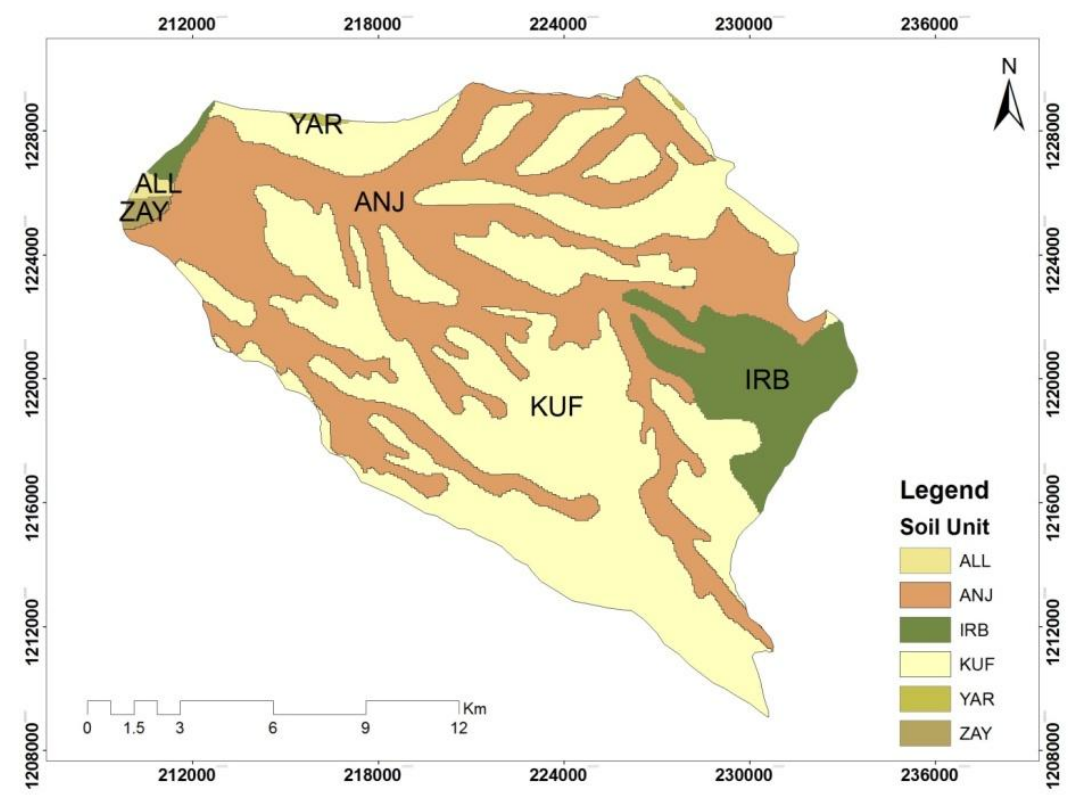

Fig.4 Landuse map of Wadi El-Arab catchment (MWI, 2016).

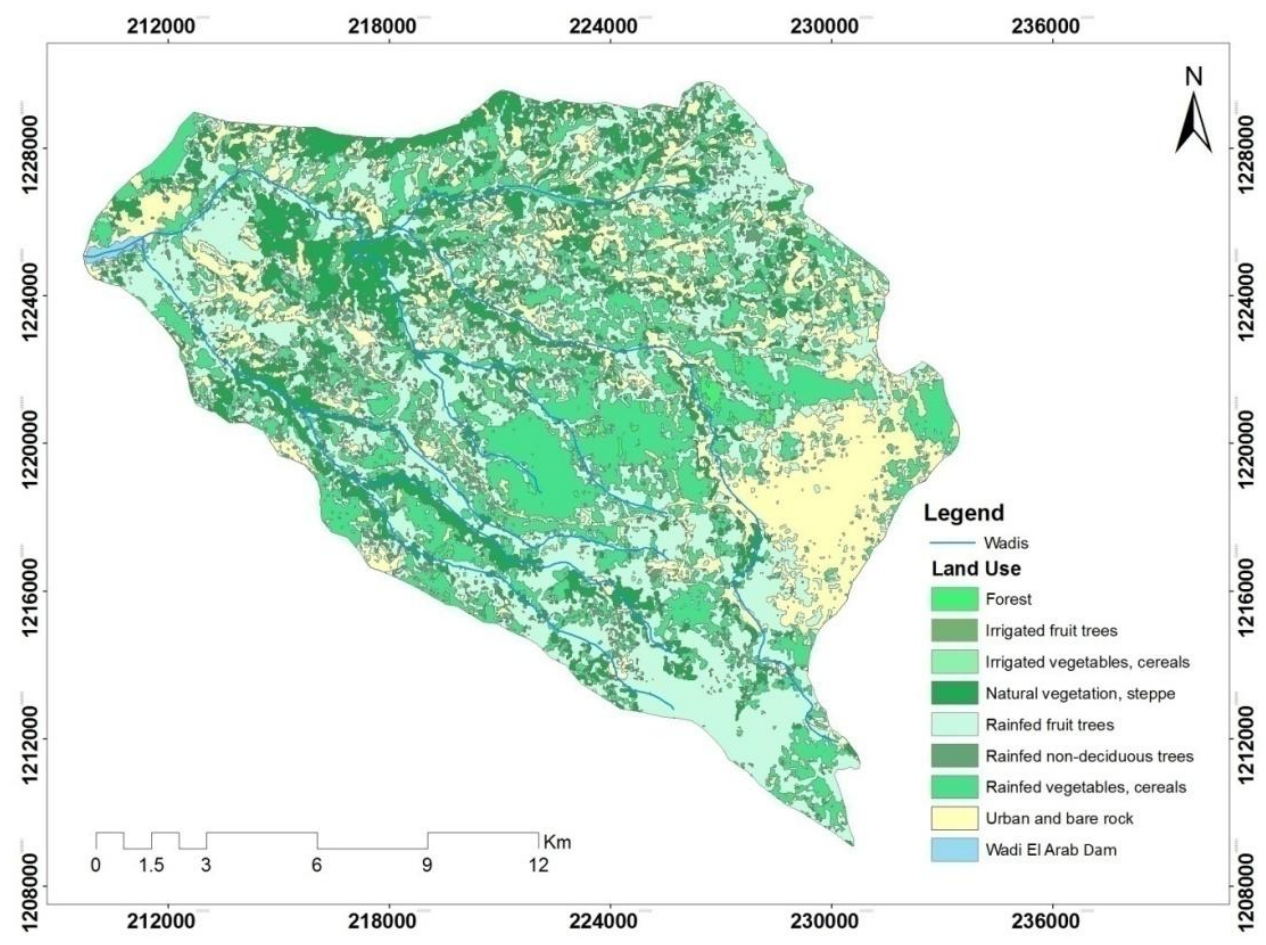


Fig.5 General geological and structural map of the Wadi El-Arab catchment (Margana, 2006).

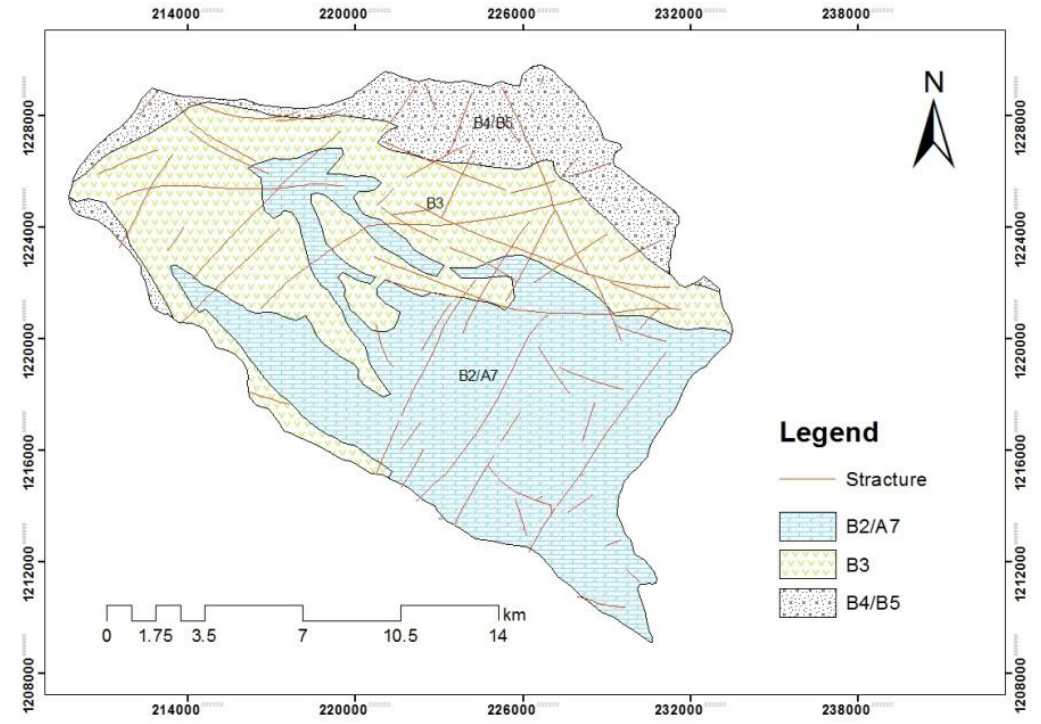

Fig.6 Thiessen polygons network of Wadi El- Arab catchment area.

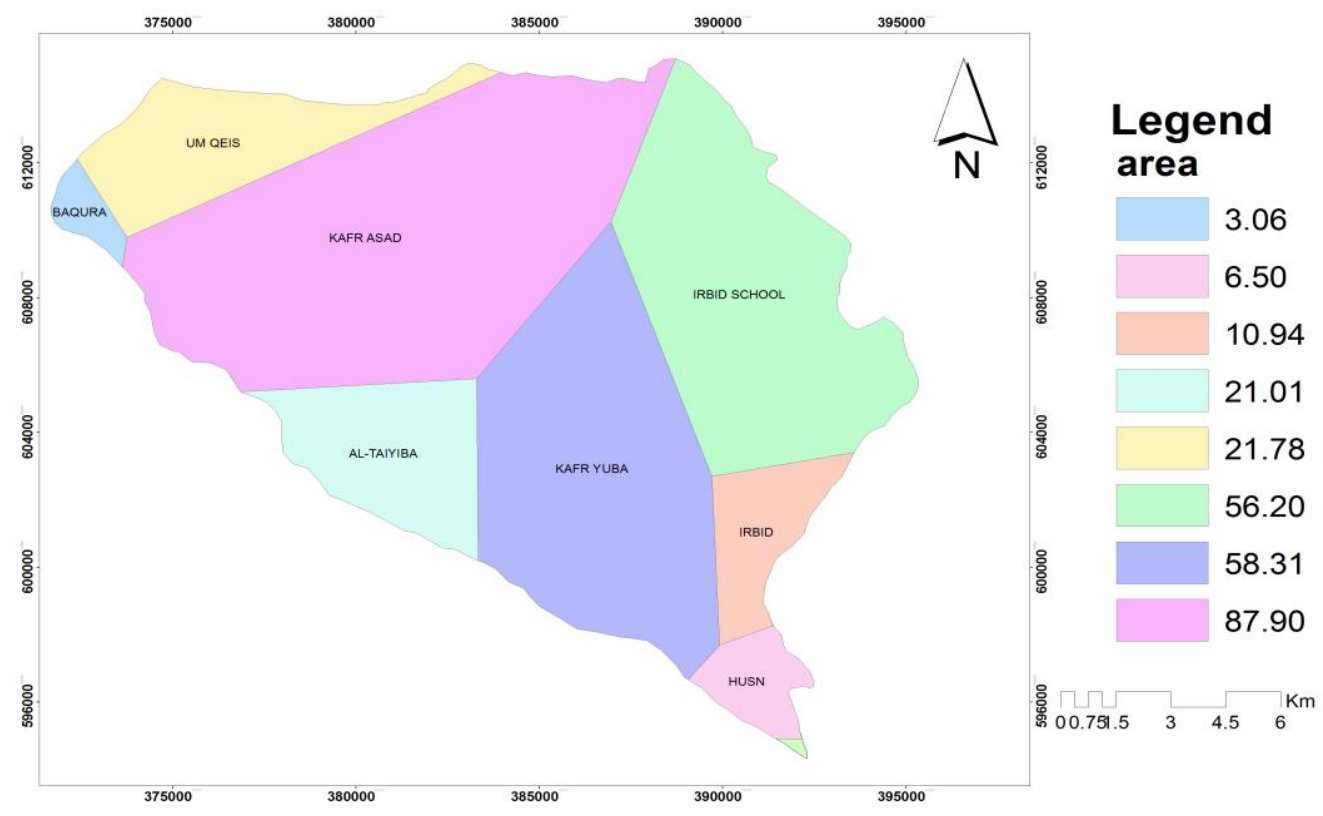


Fig.7 Groundwater Flow- net map of the Wadi El-Arab catchment.

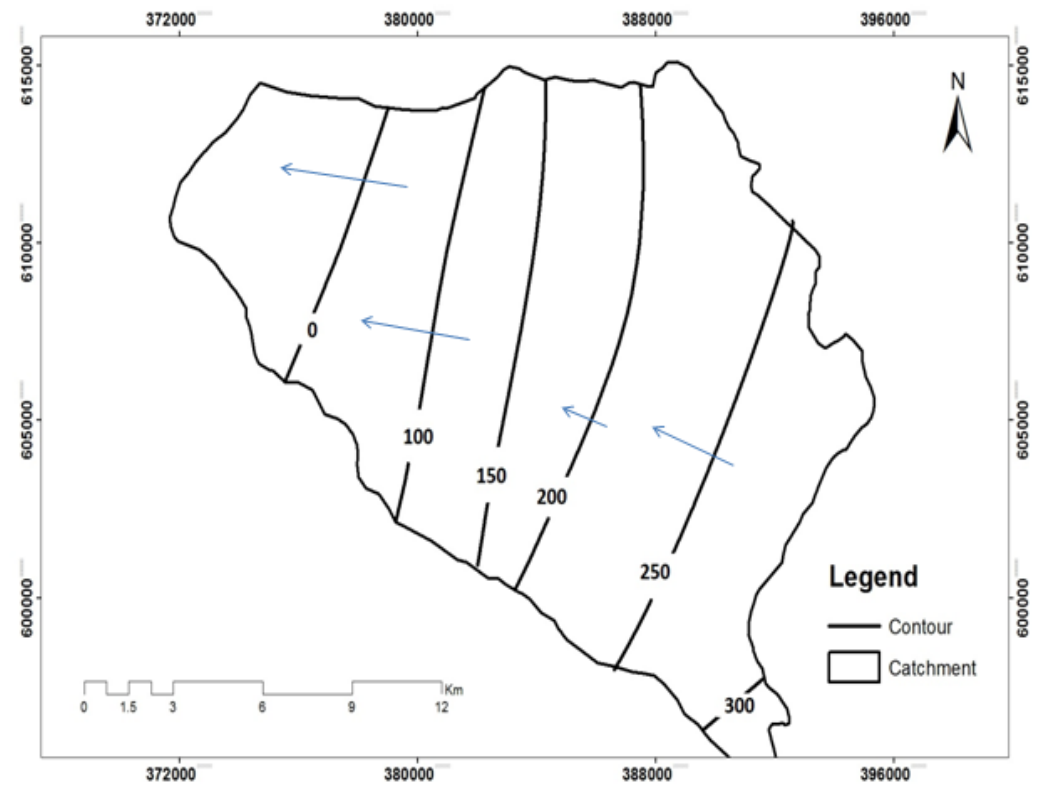

Fig.8 Isohyethal contour map of the annual rainfall averages of the Wadi El-Arab Catchment.

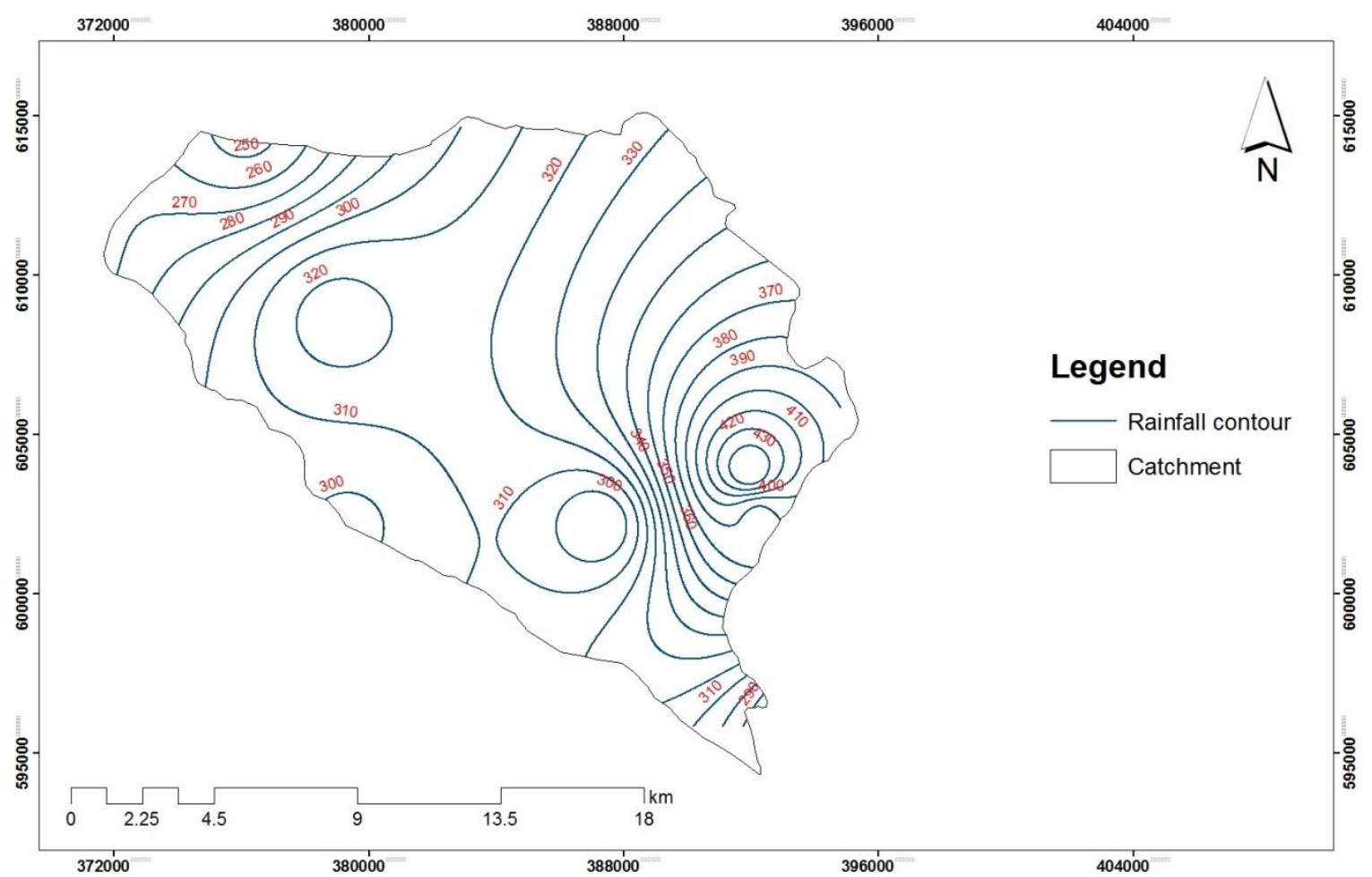

Under the assumption that, the are properly determined, then the following evapotranspiration is calculated adequately, as water balance equation can be established as: well as, the runoff and the initial abstractions 
$\Delta S=P-(R+E) \pm I_{a} \ldots$ (6), (Chow et. al, 1988)

Where:

$\Delta \mathrm{S}$ : the change of groundwater storage or recharge $(\mathrm{mm})$.

P: the precipitation in (mm).

E: evapotranspiration in (mm).

$\mathrm{R}$ : runoff in (mm)

$\mathrm{I}_{\mathrm{a}}$ : initial abstraction in ( $\left.\mathrm{mm}\right)$.

In Wadi El - Arab catchment area. The only measured parameter in this approach is the rainfall; evaporation and runoff were calculated using Turc and SCS-Curve Number method respectively. Then, the infiltration rate was found for wet, dry, and normal conditions. The results of recharge calculations are shown in Table 5 and 6.

The aquifer systems of the entire study area are related to the Cretaceous Upper Ajloun Group $\left(\mathrm{A}_{7}\right)$ to the Cenozoic Lower Belqa Group $\left(B_{1}\right.$ and $\left.B_{2}\right)$ is the main aquifer for water supply in the study area. On its top, the $\mathrm{A}_{7} / \mathrm{B}_{2}$ aquifer is hydraulically separated from the locally productive $\mathrm{B}_{4}$ aquifer by the Muwaqqar aquitard $\left(\mathrm{B}_{3}\right)$.

The saturated thickness of $\mathrm{B}_{2} \mathrm{~A}_{7}$ appears in small part, as in Irbid area, which is located at the east boundary of catchment. The direction of the groundwater flow is from eastern part of the catchment to the western part of the catchment that means from highlands to lowlands of the catchment. The transmissivity of the $\left(B_{2} / A_{7}\right)$ aquifer ranges from $9 \mathrm{~m}^{2} /$ day to more than $900 \mathrm{~m}^{2} /$ day. The storage coefficient of this aquifer in the confined condition vary from $10^{-3}$ to $10^{-5}$, while the specific capacity vary from less than $0.01 \mathrm{~L} / \mathrm{s} / \mathrm{m}$ to more than $50 \mathrm{~L} / \mathrm{s} / \mathrm{m}$ and The permeability ranges from
0.01 to more than $100 \mathrm{~m} /$ day.

The average annual rainfall of normal years is $410 \mathrm{~mm}$, the average annual rainfall of dry years is $205.39 \mathrm{~mm}$ and the average annual rainfall of wet years is $756.2 \mathrm{~mm}$ for (19952018). The runoff ranges between $1.44 \mathrm{MCM}$ (1983-1984) to 72.89 MCM (1979-1980) for the period of study. The water budget of the study area was performed for (1991-2003) and the average values were (115.15 MCM) for rainfall, (20.68 MCM, $14.46 \%$ of rainfall) for runoff, (87.44MCM, $79.37 \%$ of rainfall) for evaporation, and $(7.03 \mathrm{MCM}, 6.17 \%$ of rainfall) for infiltration.

\section{Acknowledgements}

The authors acknowledge the assistance of Technicians and Hydrologists (from the Ministry of Water and Irrigation) during the fieldwork and data collection. I am also very grateful to Dr. Tarek Ammari (Professor of Water Resources and Soil chemistry) from Al Balqa' Applied University, for providing us valuable comments and revising our manuscript. They are warmly appreciated.

\section{References}

Al-Adwan, S. 2018. Estimation of the Sediment Yield at Wadi Al-Arab Dam Using Hydrological Assessment Tool Models, Unpublished master thesis, the University of Jordan.

Aydin, E. and Antal, J. (2019). Introduction to Precipitation Runoff Process and Soil Erosion Risk Analysis in a Specific Area of Interest to Design Control Measures. Journal of Ecological Engineering 20(2).

BGR and MWI (2001). Groundwater resources of Northern Jordan. Vol. 4contributions to the hydrology of Northern Jordan. Ministry of Water and Irrigation (MWI) and Federal 
Institute for Geosciences and Natural Resources (BGR), Project No. 89.2105.8. Amman, Jordan. (unpublished).

Chow, V.T., Maidment, D.R., and Mays, L.W. (1988). Applied hydrology. McGrawHill, New York.

JMD, Jordan Meteorological Department (JMD), 2012. Annual Report, Ministry of Transport. Amman,J ordan.

Margana, A. (2006). Hydrogeological proposal for the delineation of a groundwater protection area for the Wadi Al Arab well field. Amman: Technical Cooperation Project MWI BGR, Ministry of Water and Irrigation

MOA - Ministry of Agricultural (1994). The soils of Jordan. National soil map and land use project. Hunting Technical Services Ltd. in association with Soil Survey and Land Research Centre.
Vol. 2-level 2, main report. Ministry of Agricultural, Amman, Jordan

MWI, Ministry of Water and Irrigation, 2017. Open files. Amman, Jordan.

MWI, Ministry of Water and Irrigation, 2016. Water Information System Hydrological, geological and hydrogeological data bank. Water Resources and Planning Directorate, Amman, Jordan.

Shatnawi, A., and Diabat, A. (2016). Siltation of Wadi Al-Arab Reservoir Using GIS Techniques. Jordan Journal of Civil Engineering, 10(4).

Turc, M. (1990). Hydrology and Water Quantity Control, John Wiley and Sons. Inc., USA.

Wanielista, M. (1990). Hydrology and Water Quantity Control, John Wiley and Sons. Inc., USA.

\section{How to cite this article:}

Naser Al Manaseer and RakadTa'any. 2019. Hydrological Study and Aquifer Characteristics Evaluation of Wadi El Arab Catchment Area/Jordan. Int.J.Curr.Microbiol.App.Sci. 8(11): 2058-2070. doi: https://doi.org/10.20546/ijcmas.2019.811.238 